\title{
The Mediating Effects of Employee Engagement on Motivational Factors and Job Performance
}

\section{Hussain Almawali, Nor Intan Adha Hafit, Narehan Hassan}

To Link this Article: http://dx.doi.org/10.6007/IJARBSS/v11-i12/11948

DOI:10.6007/IJARBSS/v11-i12/11948

Received: 22 October 2021, Revised: 24 November 2021, Accepted: 10 December 2021

Published Online: 28 December 2021

In-Text Citation: (Almawali et al., 2021)

To Cite this Article: Almawali, H., Hafit, N. I. A., \& Hassan, N. (2021). The Mediating Effects of Employee Engagement on Motivational Factors and Job Performance. International Journal of Academic Research in Business and Social Sciences, 11(12), 2316-2332.

\section{Copyright: @ 2021 The Author(s)}

Published by Human Resource Management Academic Research Society (www.hrmars.com)

This article is published under the Creative Commons Attribution (CC BY 4.0) license. Anyone may reproduce, distribute, translate and create derivative works of this article (for both commercial and non0-commercial purposes), subject to full attribution to the original publication and authors. The full terms of this license may be seen at: http://creativecommons.org/licences/by/4.0/legalcode

Vol. 11, No. 12, 2021, Pg. 2316- 2332

Full Terms \& Conditions of access and use can be found at http://hrmars.com/index.php/pages/detail/publication-ethics 


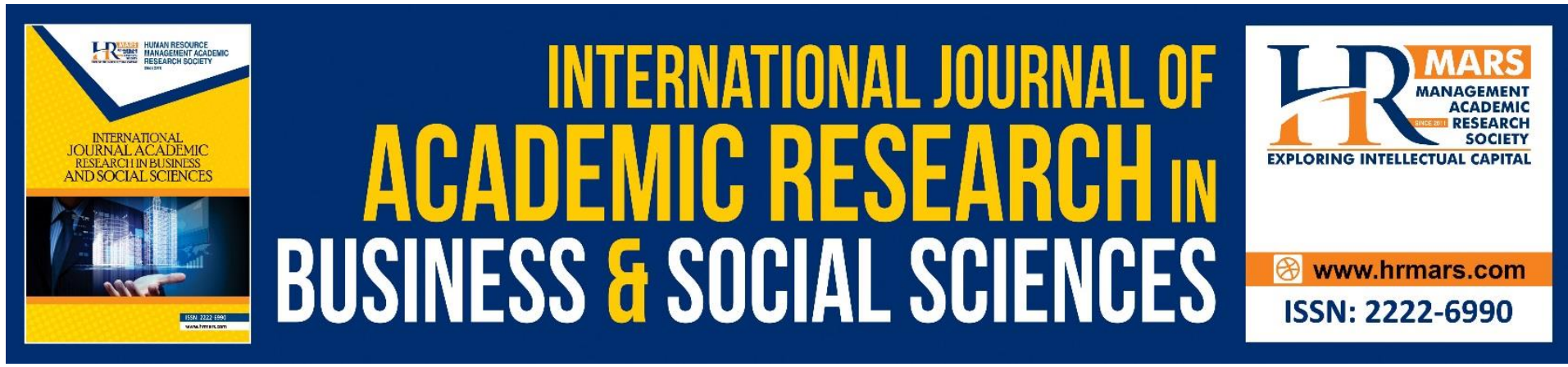

\title{
The Mediating Effects of Employee Engagement on Motivational Factors and Job Performance
}

\author{
Hussain Almawali, Nor Intan Adha Hafit \\ Faculty of Business and Management, Universiti Teknologi MARA Jalan IImu 1/1, 40450 \\ Shah Alam, Selangor, Malaysia \\ Narehan Hassan \\ Faculty of Business and Management, Universiti Teknologi MARA Puncak Alam, 42300 \\ Kuala Selangor, Selangor, Malaysia
}

\begin{abstract}
The goal of this research is to examine the relationship between motivational variables, work performance, and employee engagement, as well as the effect of motivational factors on job performance in the Sultanate of Oman's government sector using employee engagement as a mediator. The study used a quantitative approach and evaluated six hypotheses with the assistance of 150 representative government employees from the Ministry of Education. This is preliminary research. Quota sampling was utilized in this study, and data were analyzed using the Statistical Package for the Social Sciences (SPSS) and path analysis techniques. The study's findings indicate that these aspects are favorably connected, that motivating factors are positively associated with employee engagement and job performance, and that employee engagement acts as a partial mediator in the relationship between motivating factors and job performance. This research is critical for public sector executives and regulators concerned with job performance improvement in Oman. This is one of the few studies that investigate the mediating function of employee engagement in the link between motivational traits and job performance. This is one of the first studies of its kind conducted in Oman for the public sector. Other driving factors may be investigated and evaluated in the private sector in future research.
\end{abstract}

Keywords: Motivational Components, Job Performance, Employee Engagement, and The Government Sector of The Sultanate of Oman

Organizational performance is a critical factor in people management (June \& Mahmood, 2011) and has grown to be a critical component of an enterprise's success (Ahmad et al., 2018). The leadership of the institution is devoted to improving employee performance via effective communication and motivating techniques (Ahmed et al., 2016). Staff success is crucial to an organization's purpose and commercial objectives, and employee efficiency is critical to an institution's development (June et al., 2013). To attain these goals, the company's regulatory authority adopts several strategies and processes that are meant to 
enhance efficiency in a variety of operational conditions and to provide the best possible results for the organization via employee efforts (Ahmed et al., 2016).

Attaining targets requires crucial employees (Mohamed et al., 2020). Increased efficiency results in fewer organizational challenges. Employees are a company's most asset (Detienne et al., 2020).

Various studies have shown an unambiguous correlation between job satisfaction and performance (Anitha, 2014; e.g., Gorgievski et al., 2010; Dajani, 2015; Ismail et al., 2019). Numerous studies have shown that touch improves outcomes. Without regard for work performance, businesses would be unable of energizing and encouraging employees to accomplish their goals (Dess et al., 2006; Ghaffari et al., 2017). According to psychologists, firms that place a higher premium on employee performance through motivation and engagement will be better able to motivate staff to achieve goals (Aarabi et al., 2013). According to Detienne et al (2020), communicating the positive value of tasks as motivating resources significantly increases employee engagement more than discussing the negative consequences of an incomplete job, and framing tasks and jobs in terms of rewards significantly increases their expected attractiveness and inner drive.

Work output is characterized and perceived differently in research and industry. Lawler and Porter (1967) defined job performance as the contribution of an individual's qualities, skills, and effort to a situation. Bernardin and Beatty (1984) defined job performance as a database that stores data on the outputs of a work process or activity over a specified time period. Job output, according to Hunter (1986), is the result of an employee's work. Campbell (1990) defined job success as "the actions or behaviors that contribute to the accomplishment of the organization's objectives" and employee success as "the aggregated financial or nonfinancial contribution made by employees to the accomplishment of the organization's goals both internally and externally." Borman and Motowidlo (1993) described job performance as having three critical components: (a) it must be defined in terms of behavior rather than results, (b) it must be restricted to activities that contribute to the institution's objectives, and (c) it must be a multidimensional concept. Work performance, as described by Viswesvaran and Ones (2000), is defined as the adaptive actions, behaviors, and outcomes that workers participate in or bring about that contribute to the achievement of institutional objectives. According to Price (2001), employee output is an individual's alignment with their employment. The word "performance" refers to the monetary worth associated with an individual's or a team's work (Reynoldsa et al., 2020). Griffin (2007) defined work output as the total of the activities and behaviors of an employee. Pushpakumari (2008) defined job output as the worker's purpose in terms of effort. Additionally, Addair et al (2019) defined job success as the value that workers provide to their employers. The degree to which an individual's duties and responsibilities are met is used to assess his or her job performance. When analyzing employment outcomes, it is necessary to examine both the number of available jobs and the kind of labor (Reynoldsa et al., 2020). Addair et al (2019) defined job performance as "all employee behaviors and activities that may impact the recruiting institution's outcomes." Job output may be described as the behavior of employees that has an effect on the institution's outcomes (Jalalkamali et al., 2016). Employee success is a nuanced and perplexing phenomenon in contemporary society, molded by a network of shared values, responsibilities, and objectives across cultures (Aliekperova, 2018). 
Various factors, including the person and the work environment, influence job performance (Tripathy, 2013). Tamkin (2005) contended that collaboration would boost work efficiency. Outstanding capabilities and preparation contribute to the success of a company (Misra, 2013). According to Searle et al. (2001), social support benefits workers by boosting their performance. According to George (2000), emotional intelligence plays a part in professional success. Ghaffari et al (2017) determined that the following factors related to higher work efficiency: remuneration, fringe benefits, monitoring, advancement, accountability, and readiness. Salary, job stability, advancement possibilities, freedom, a nice work environment, and readiness are all considered career success criteria by Aarabi et al (2013). According to Dajani (2015), job efficiency is impacted by factors such as leadership, organizational justice, compensation and benefits, work practices and procedures, and readiness. Numerous theories address human wants, including Herzberg's two-factor hypothesis, Vroom's expectation theory, and Maslow's want theory (Ghaffari et al., 2017).

The goal of this study is to establish a link between job performance and motivational characteristics (work environment and leadership). The goal of this research is to investigate the moderating effect of employee engagement on the link between work environment, leadership, and performance. The Sultanate of Oman's government sector was the subject of this research, with the Ministry of Education acting as a case study.

\section{The Study's Problem}

Many public institutions across the world have faced fiscal hardship because of poor job performance. Depression diagnoses among millennials and teenagers are growing at a faster pace than in any previous generation, according to a Blue Cross Blue Shield survey. In any event, the sickness is expected to cost the US \$44 billion in lost productivity per year (Detienne et al., 2020).

Oman continues to suffer from substandard public sector performance. Now, the public sector lacks meaningful performance indicators. Performance is low regardless of the approach used, institutional or human (Orabi, 2020). Diversification of the economy and development of the national gross domestic product are impossible to achieve unless and until government bodies improve their performance (Orabi, 2020). It is critical to carry out actions and initiatives aimed at enhancing government performance (Almatani, 2020).

The goal of this research is to get a better knowledge of the work environment and leadership as motivating elements impacting workplace performance in the Sultanate of Oman's public sector, with a particular emphasis on the Ministry of Education. Government authorities in the Sultanate of Oman may profit from this research when establishing policies and procedures for inspiring and motivating employees to continue achieving company goals.

Furthermore, by analyzing the mediating function of employee engagement, the present research adds to a better understanding of the link between motivation and performance.

\section{Development of Literature and Hypotheses In the Sultanate of Oman, the public sector}

The Sultanate of Oman is an Arab Muslim state located in western Asia on the Arabian Peninsula. It has a total population of around 4.6 million people, with 58 percent of the population being Omani and the remaining being foreign nationalities. Oman is classified as a Sultanate with a middle-income status. Oman earns most of its income from oil and gas. In 
2019, Oman employed over 2.4 million workers. Oman's Sultanate is divided into fifteen authorities and twenty-three ministries, all of which are governed by labor legislation (National Centre for Statistics and Information (NCSI, 2019).

\section{Factors Affecting Motivation and Work Performance}

Numerous factors influence motivation. In this research, the work environment and leadership will be studied as motivating factors. Employee performance is crucial because it helps workers to focus on the most vital aspects of their professions (Dajani, 2015).

Roca et al (2006) identified a positive association between a positive work environment and job performance in many institutions. Additionally, Jamal (2007) explored the link between a difficult work environment and an individual's motivation to engage in the organization of North American enterprises, as cited in Aarabi et al (2013). According to the study, most firms believe that a hostile work atmosphere has a negative correlation with job efficiency. This means that if the workplace is typically unpleasant, administrators should create a framework that supports a positive work atmosphere that motivates individuals (Hourani et al., 2006). As a result, leadership must be important in promoting a good work atmosphere. The work environment, according to Aarabi et al (2013), has a direct influence on employee performance. When workers are anxious, a significant percentage of them are likely to abandon their occupations (Chen \& Lien, 2008).

Effective leadership behavior that promotes self-awareness, knowledge sharing, openness, and commitment to the company's core values (Dajani, 2015). Leadership may be described as the process by which administrators excite their personnel intellectually and psychologically in order for them to feel confident and valued while doing their given jobs, hence enhancing their performance (Gözükara \& Imşek, 2015). Employee performance contributes to career productivity and engagement in the workplace (Walumbwa \& Hartnell, 2011). Management and leadership's key objective is to boost workers' performance in order to ensure their continued success (Manzoor et al., 2019). According to Naeem and Khanzada (2018), there is a strong correlation between leadership and job performance. As a result, the following are the first and second hypothesis ( $\mathrm{H} 1 \& \mathrm{H} 2)$ :

H1: There is a significant relationship between work environment and job performance.

H2: There is a significant relationship between leadership and job performance.

\section{Engagement of Employees and Job Performance}

When employees are engaged, they recruit and integrate many elements of their cognitive and psychological identities to transform professional responsibilities and extraordinary connections into visible accomplishments (Byrne, 2014). Individuals with a high level of involvement, in compared to disengaged employees, are enthusiastic about their employment, devoted to their areas, and demonstrate their dedication to their enterprises (Ismail et al., 2019).

According to Parker and Griffin (2011), organizational commitment enhances work performance by instilling good attitudes and increasing drive to execute given tasks and activities. Employee motivation influences job performance (Stairs \& Galpin, 2009). Employee engagement, evidence-based research suggests, has a direct influence on work performance (Ismail et al., 2019). Gorgievski et al (2010), for example, used a multidimensional method to 
explore the relationship between employee engagement and success among 54 Dutch educators. They established the presence of a positive correlation. This conclusion is consistent with Gorgievski et al. (2010), who conducted a 1.5-year analysis of 2,162 workers and determined that employee behavior had a significant impact on the project's quantitative and qualitative outcomes. Employee motivation and work performance are inextricably linked, as Anitha (2014) and Ismail et al (2019) proved. Numerous earlier research have shown a direct correlation between employee motivation and job performance, since driven people are anticipated to perform at a better level than non-motivated employees (Demerouti \& Cropanzano, 2010). As a result, hypothesis three (H3) is as follows:

H3: There is a significant relationship between employee engagement and job performance.

\section{Employee Engagement and Motivational Factors}

Both the workplace and leadership settings include motivational elements. Because it has a good correlation with employee performance. The work environment has a considerable effect on employee engagement (Anitha, 2014). The work environment is described as "a physically and emotionally safe atmosphere that stimulates individuals to perform well" (Anitha, 2014, p. 318). Numerous studies indicate that employee engagement seems to be influenced by several organizational factors (Miles, 2001; Holbeche \& Springett, 2003; Rich et al., 2010). According to Deci and Ryan (1987), management that supports a pleasant work environment is typically concerned with workers' wishes and feelings, gives constructive feedback, and enables employees to voice complaints, gain new skills, and resolve jobrelated difficulties (Anitha, 2014).

Leadership is a critical trait that has been cited as a critical component in educating people about employee engagement (Anitha, 2014). According to Walumbwa et al. (2008), successful leadership involves a range of abilities, including self-awareness, logical knowledge acquisition, social openness, and internalized moral standards. Engagement develops organically when leaders inspire their staff (Wallace \& Trinka, 2009). Leaders are accountable for ensuring that workers' contributions to the organization's success are vital (Anitha, 2014). Leaders should put a lesser focus on challenging an employee's accountability and a larger premium on human characteristics that promote motivation and positive engagement (Hawley, 1993). When workers think their leadership appreciates their efforts, they become more motivated and invested in the organization (Anitha, 2014). Employer-employee coordination may influence employee morale: a boss who interacts effectively with aides may enhance workplace motivation in such personnel (Lockwood, 2007). It is predicted that accurate and inclusive leadership would boost workers' commitment, satisfaction, and passion for their employment (Schneider et al., 2009). As a result, hypotheses 4 and 5 (H4 \& H5) have the following form:

H4: There is a significant relationship between work environment and employee engagement. H5: There is a significant relationship between leadership and employee engagement.

Additionally, businesses use a variety of technologies to facilitate communication in order to enhance efficiency and performance (Dajani, 2015). Employee commitment helps the business succeed by producing good sentiments and increasing enthusiasm for work duties 
and responsibilities (Ismail et al., 2019). When workers are pleased with their salary and recognition inside their firm, the majority react with a high degree of commitment (Saks, 2006). Economic incentives have a major impact on staff productivity and performance (Swapna \& Narayanamma, 2019). Numerous organizations have used financial incentives to both motivate and retain personnel, as well as to increase production (Woodruffe, 2000; Cappelli, 2000; Mehrzi, \& Singh, 2016). Numerous organizations use financial incentives to boost employee satisfaction and productivity (Hongal et al., 2020).

Commitment is the most important advantage to a company since it has a direct impact on how employees do their jobs and results in increased engagement in a supportive work environment (Dajani, 2015; Ahakwa et al., 2021). Leaders can significantly contribute to the creation of a pleasant work environment that fosters employee passion and productivity (Kahn, 1990; May et al., 2004).

Job atmosphere is a significant motivator since it involves "working environments, tools available to employees, and administrators' ethical behavior" (Rasheed et al., 2016, p. 109). By establishing an appropriate work environment, it is possible to boost job efficiency (Shah et al., 2010). When employees have confidence in their leadership and work environment, they invest. Both variables contribute to one's mental and emotional health (Koyuncu et al., 2006; May et al., 2004). Employee engagement functions as a mediator between the work environment, leadership, and job performance, as proven by Dajani (2015) and Ahmed et al. (2016). As a result, hypothesis 6 (H6) is the following:

H6: Employee engagement mediates the relationship between motivational factors and job performance.

\section{Conceptual Framework}

The purpose of this research was to determine if work performance, as a dependent variable, had a substantial link with employee engagement and motivating variables. Employee involvement is also a mediator in the conceptual model. The conceptual foundation for this investigation is shown in Figure 1.

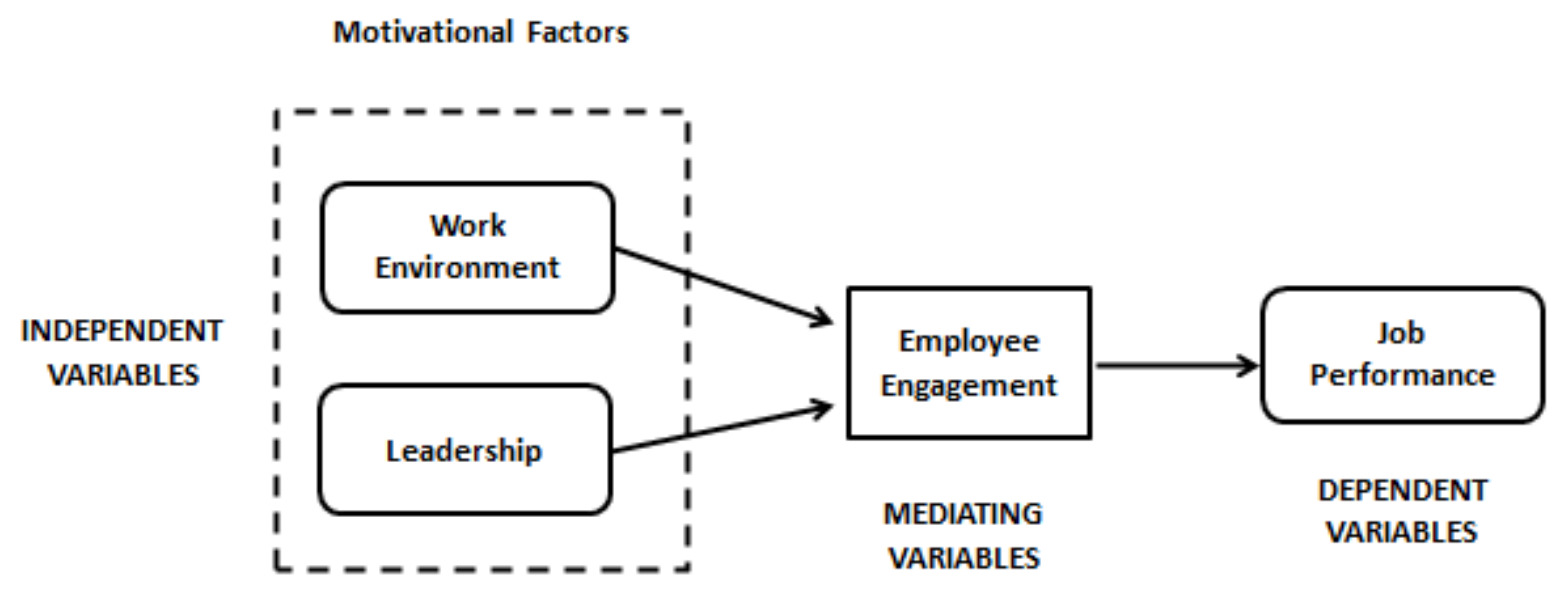

Figure 1. Research Framework 


\section{Method}

This study used a causal descriptive quantitative analytic method based on a survey of the literature. While descriptive statistics are used to summarize data, causal statistics are used to demonstrate the relationship between variables. SPSS and route analysis were used to perform the investigation. The phrase "path mapping" is often used to refer to linkages that are both direct and indirect (Riduwan, 2012).

\section{Population}

A population is a fictitious group of persons for whom the researcher seeks to generalize the results of his or her investigation (Shepherd et al., 2017). This was a pilot study. The demographic for this study is current workers of the Ministry of Education. Operationally, these government workers will be classified as those who work in a ministry and have at least one year of work experience.

\section{Sampling Methods}

The phrase "sampling" refers to the process of selecting enough correct items from a population (Sekaran \& Bougie, 2010). To recruit participants for this research, quota sampling was used, which often enables the author to exercise only a limited degree of control on the survey's selectivity, therefore eliminating bias during the selection step. The quota for this study was determined by the number of workers with at least one year of experience at the Ministry of Education.

\section{Sample Size}

There were 150 contestants in all. Krejci and Morgan (1970) were used as a guide for calculating an appropriate sample size for the 150-person study population. The sample size is 150 workers using the Krejcie-Morgan formula. Hair et al (2010) advocated for examining at least 100 responders.

\section{Validity}

The term "content validity," or "facial validity," refers to a subjective assessment of the degree of congruence between the scale's questions and their theoretical rationale (Hair et al., 2010). The purpose of this research is to determine the content validity of the questions assessed by assessing their effectiveness in addressing all facets of the subject.

\section{Reliability}

The word "reliability" refers to the degree to which a measurement remains consistent over time or the amount of time necessary to replicate results (Bryman, 2008). George and Mallery's (2010) "rules of thumb" were used to assess these analytic results. The outcomes of the study's reliability evaluation, which included employee engagement, work performance, and motivating variables, are summarized in Table 3.8. The investigation's findings established that the instrument was appropriate for this study. The researcher chose the objects to be used. Employee engagement, motivational traits, and work performance all have Cronbach's Alpha values better than 0.8 , indicating a strong and positive correlation between the metrics. 
Table 1. Findings from the Reliability Analysis

\begin{tabular}{ll} 
Variables & Cronbach's Alpha value \\
\hline Employee & \\
Engagement & 0.919 \\
\hline Motivational Factors & 0.913 \\
\hline Job Performance & 0.921 \\
\hline
\end{tabular}

Table 2. Demographics Characteristics

\section{Classificatio}

\begin{tabular}{|c|c|c|c|}
\hline Demography & $\mathbf{n}$ & Participants & $\%$ \\
\hline \multirow{3}{*}{ Gender } & male & 87 & $58 \%$ \\
\hline & & & \\
\hline & female & 63 & $42 \%$ \\
\hline \multirow{5}{*}{ Age } & $<25$ & 13 & $9 \%$ \\
\hline & $>26-35$ & 41 & $27 \%$ \\
\hline & $>36-45$ & 87 & $58 \%$ \\
\hline & $>46-55$ & 9 & $6 \%$ \\
\hline & $>56$ & 0 & $0 \%$ \\
\hline \multirow{7}{*}{$\begin{array}{l}\text { Educating } \\
\text { level }\end{array}$} & High School Degree & 0 & $0 \%$ \\
\hline & 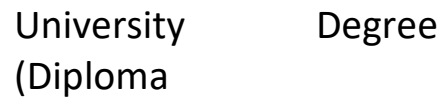 & & \\
\hline & \& Bachelor) & 7 & $4 \%$ \\
\hline & Master's degree/MBA & 103 & $69 \%$ \\
\hline & $\mathrm{PhD}$ & 40 & $27 \%$ \\
\hline & Other & & \\
\hline & Degrees & 0 & $0 \%$ \\
\hline \multirow{6}{*}{$\begin{array}{l}\text { Experimenta } \\
\text { tion at work }\end{array}$} & $<5$ years & 18 & $11 \%$ \\
\hline & $>6-10$ years & 27 & $18 \%$ \\
\hline & $\begin{array}{ll}> & 11-15 \\
\text { years }\end{array}$ & 52 & $35 \%$ \\
\hline & $>\quad 16-20$ & & \\
\hline & years & 46 & $31 \%$ \\
\hline & $>21$ years & 7 & $5 \%$ \\
\hline
\end{tabular}

This research distributed surveys by questionnaire and was based on Rich et al (2010)'s definition of employee engagement, Ramos et aldefinition.'s of job performance, and Majdalawi's definition of training (2015). Each question was constructed using the Likert scale (1-6). This study sent 170 questionnaires and received 150 valid responses. This section details the demographics of the institution's employees. Males made up most participants (58), while females made up 42. Most respondents had earned a master's or doctorate degree. Nearly $71 \%$ of employees have worked for the government for more than ten years. 
Cronbach's alpha was used to assess the dependability of the items; the majority were classified as excellent, with a Cronbach's Alpha score more than 0.9; all variables are accurate. In this work, the bootstrapping approach macro was used to determine the importance of indirect effects (Hayes, 2018). Bootstrapping is a widely used approach for circumventing sample-based assumptions (Kozlov et al., 2019).

\section{Results}

The correlations between constructs are shown in Table 3, along with their means and standard deviations. Employee engagement is positively related to employee motivation (training and compensation). With adequate data to support the assumption, one may conclude that motivating factors $(=0.443, \mathrm{SE}=0.283, \mathrm{p}=0.00)$ contribute to the preservation of $\mathrm{H} 1$ and $\mathrm{H} 2$. The results indicate that in the Sultanate of Oman's government sector, job performance is positively influenced by motivating variables $(=-0.102, \mathrm{SE}=0.123, \mathrm{p}=0.00)$ that work in concert to maintain $\mathrm{H} 3$, and that job performance is positively influenced by employee engagement $(=0.734, \mathrm{SE}=0.072, \mathrm{p}=0.00)$. This is compatible with the $\mathrm{H} 4$ and $\mathrm{H} 5$ hexadecimal systems.

Table 3. Correlation

Motivational Factors Employee Engagement

\begin{tabular}{|c|c|c|c|c|c|c|}
\hline & Coeff & SE & p-value & Coeff & SE & p-value \\
\hline \multicolumn{7}{|l|}{ Employee } \\
\hline Engagement & 0.443 & 0.283 & 0.000 & - & - & - \\
\hline Job Performance & -0.102 & 0.123 & 0.000 & 0.734 & 40.072 & 0.000 \\
\hline \multirow[t]{4}{*}{ Constant } & 2.024 & 0.116 & 0.000 & 1.601 & 10.332 & 0.000 \\
\hline & R Square & \multicolumn{2}{|l|}{0.164} & \multicolumn{3}{|c|}{ R Square 0.485} \\
\hline & $\mathrm{F}=$ & \multicolumn{2}{|c|}{10.609} & $F=$ & \multicolumn{2}{|l|}{102.729} \\
\hline & $P=$ & \multicolumn{2}{|c|}{0.000} & $P=$ & \multicolumn{2}{|l|}{0.000} \\
\hline
\end{tabular}

As seen in Table 4, their significance is assessed to ascertain whether employee engagement functions as a moderator in the relationship between job performance and motivational factors. In conclusion, indirect motivating variables have an impact on job performance (this contributes to the maintenance of $\mathrm{H} 4$ and $\mathrm{H} 5)$, and the anticipated effect is $(=0.2862)$. Additionally, common error and confidence intervals are supplied to facilitate bootstrapping from the start. $b$-values range from 0.1152 to 0.4432 for the indirect impact. $A 0$ is eliminated from this scale since it depicts projected results. Employee engagement is a component that connects employee motivations to work performance; this aspect helps to the preservation of $\mathrm{H} 6$. 
Table 4. Employee Engagement's Indirect Effect on the Relationship Between Motivational Factors and Job Performance

Effect of Motivational Factors on Job Performance

\begin{tabular}{llll} 
Effect & Boot SE & BootLLCl & BootULCl \\
\hline
\end{tabular}

\title{
Motivational Factors ->
}

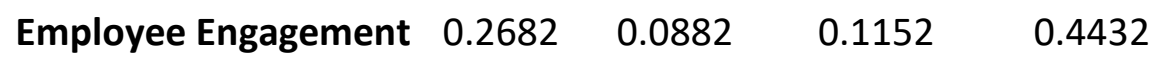

\author{
-> Job Performance
}

\section{Discussion}

The goal of this research was to ascertain the link between motivational factors, employee engagement, and job performance in Oman's public sector, as well as the effect of motivational factors on these variables. Employee engagement and job performance are influenced by a variety of elements, most notably motivational factors.

The preceding findings are consistent with those of Aarabi et al (2013) in the Malaysian service industry, Mensah and Tawiah (2016) in Ghanaian mining companies, and Ghaffari et al (2017) in a case study at Universiti Teknologi Malaysia, who discovered a significant and positive relationship between motivations and job performance. Furthermore, Anitha (2014) revealed a positive and significant correlation between engagement and job performance. As with Aguenza et al. (2018)'s findings, research has shown that when a person's interests and motivations align, engagement is likely. Additional empirical data has been uncovered that substantiates the concept that motivation has a major impact on work performance (Ghaffari et al., 2017).

The outcomes of this research indicate that the mediator may have an effect on the relationship between the independent and dependent variables. Because these traits influence job performance, this study hypothesizes that employee engagement functions as a partial mediator between motivational factors and overall job success, as Dajani (2015) and Ahmed et al. confirm (2016). Motivation is such a powerful force that it has a direct effect on work performance and employee engagement. Additionally, research shows that managers may benefit from including motivational components into their work performance and directing strategies that are reinforced and driven by staff engagement.

This endeavor is not without limitations; the data collected does not include all levels of government. Because the data for this study were collected from a single source at a particular moment in time, common method bias cannot be eliminated; however, future research may gather repeated samples from the same population over an extended period. In general, this research established a strong association between motivational characteristics, employee engagement, and job performance for government workers in the Sultanate of Oman. When a manager integrates a dimension of motivational aspects, job 
performance improves. In this way, employee engagement acts as a buffer between the variables of motivational factors and work performance.

\section{Recommendations for More Research}

The study's findings indicate that a link exists between motivational elements and job performance, and that employee engagement acts as a mediator in that relationship. This report is critical for executives in the public sector and regulators looking to improve job performance in Oman. In practice, managers should improve the work environment to get better outcomes. The study's results should be independently confirmed in the private sector.

\section{References}

Aarabi, M. S., Subramaniam, I. D., \& Akeel, A. B. A. A. B. (2013). Relationship between motivational factors and job performance of employees in malaysian service industry. Asian Social Science, 9(9), 301-310. doi:10.5539/ass.v9n9p301

Aguenza, B. B., \& Som, A. P. (2018). Motivational Factors of Employee Retention and Engagement in Organizations.

Ahmad, A., Ibrahim, R., \& Bakar, A. (2018). Factors influencing job performance among police personnel: An empirical study in Selangor.Management Science Letters, 8(9), 939-950. https://doi.org/10.5267/j.msl.2018.6.014

Ahakwa, I., Yang, J., Tackie, E. A., \& Atingabili, S. (2021). The Influence of Employee Engagement, Work Environment and Job Satisfaction on Organizational Commitment and Performance of Employees: A Sampling Weights in PLS path Modelling. https://doi.org/10.33215/sjom.v4i3.641

Al Mehrzi, N., \& Singh, S. (2016). Competing through employee engagement: a proposed framework. International Journal Of Productivity And Performance Management, 65(6), 831-843. doi: 10.1108/ijppm-02-2016-0037

Aliekperova, N. (2018). Motivating Factors Effecting Work Efficiency of Employees in

Ukrainian Pharmaceutical Sector. Economics \& Sociology, 11, 61-74. https://doi.org/10.14254/2071-789X.2018/11-1/4

Alderfer, C. P. (1972). Existence, relatedness, and growth: Human needs in organizational settings. New York: Free Press.

Anitha, J. (2014). Determinants of employee engagement and their impact on employee performance. International Journal of Productivity and Performance Management, 63, 308-323. https://doi.org/10.1108/IJPPM-01-2013-0008

Azeem, M. F., \& Paracha, A. (2013). Connecting Training and Development with Employee Engagement: How Does it Matter?

Baker, S., \& Asiimwe, S. B. (2014). Does training influence employee performance in regulatory organizations in Uganda? Empirical evidence from UCC.

Bao, C., \& Nizam, I. (2015). THE IMPACT OF MOTIVATION ON EMPLOYEE PERFORMANCE IN THE ELECTRONICS INDUSTRY IN CHINA. https://doi.org/10.24924/ijabm/2015.11/v3.iss2/29.45

Bernardin, H. J., \& Beatty, R. (1984). Performance appraisal: assessing human behavior at work.

Bhuvanaiah, T. (2014). Employee Engagement: Key to Organizational Success. SCMS Journal of Indian Management. 
Borman, W. C., \& Motowidlo, S. (1993). Expanding the Criterion Domain to Include Elements of Contextual Performance.

Bryman, A. (2008). Social research methods (3rd ed.). Oxford: Oxford University Press.

Byrne, Z. S. (2014). Understanding Employee Engagement: Theory, Research, and Practice. https://doi.org/10.4324/9780203385944

Campbell, J. P. (1990). Modeling the performance prediction problem in industrial and organizational psychology.

Cappelli, P. (2000). A Market-Driven Approach to Retaining Talent. Harvard Business Review, 78.

Dajani, Z. (2015). The impact of employee engagement on organisational performance. South African Institute for Chartered Accountants Conference, 3(5), 288-295.

Demerouti, E., \& Cropanzano, R. (2010). From thought to action: employee work engagement and job performance.

Dess, G. G., Peridis, T., \& Lumpkin, G. T. (2006). Strategic management: Creating competitive advantages. Toronto: McGraw-Hill Ryerson.

DeTienne, K., Hooley, J., Larrocha, C., Reay, A. (2020). How to manage an employee with depression. Harvard Business Review. https://hbr.org/2020/01/how-to-manage-anemployee-with-depression

Garavan, T., McCarthy, A. M., Lai, Y., Murphy, K., Sheehan, M., \& Carbery, R. (2020). Training and organisational performance: A meta-analysis of temporal, institutional, and organisational context moderators. Human Resource Management Journal. https://doi.org/10.1111/1748-8583.12284

George, J. (2000). Emotions and Leadership: The Role of Emotional Intelligence. Human Relations, 53, 1027 - 1055. https://doi.org/10.1177/0018726700538001

George, D., \& Mallery, P. (2010). SPSS for Windows step by step: A simple guide and reference.

Ghaffari, S., Shah, I., Burgoyne, J., Nazri, M., \& Salleh, J. R. (2017). The Influence of Motivation on Job Performance: A Case Study at Universiti Teknoligi Malaysia. Development Economics: Regional \& Country Studies eJournal.

Gorgievski, M., Bakker, A., \& Schaufeli, W. (2010). Work engagement and workaholism: comparing the self-employed and salaried employees. The Journal of Positive Psychology, 5, 83 - 96. https://doi.org/10.1080/17439760903509606

Griffin, M., Neal, A., \& Parker, S. (2007). A new model of work role performance: Positive behavior in uncertain and interdependent contexts. Academy of Management Journal, 50, 327-347. https://doi.org/10.5465/amj.2007.24634438

Hair, J. F., Black, W. C., \& Babin, B. J. (2010). Multivariate Data Analysis: A Global Perspective (7th ed.).

Hayes, A. (2018). Partial, conditional, and moderated moderated mediation: Quantification, inference, and interpretation. Communication Monographs, 85, 4 - 40. https://doi.org/10.1080/03637751.2017.1352100

Herzberg, F., Mausner, B., \& Snyderman, B. B. (1959). The motivation to work.

Hicks, R., O'Reilly, G., \& Bahr, M. (2014). Organisational engagement and its driving forces: A case study in a retail travel organisation with international outreach. International journal of management cases, 16, 4-19.

Holston-Okae, B. L. (2017). Employee Turnover Intentions in the Hospitality Industry. Hongal, P., \& Kinange, U. (2020). A Study on Talent Management and its Impact on Organization Performance- An Empirical Review. International Journal of Engineering and Management Research, 10, 64-71. https://doi.org/10.31033/ijemr.10.1.12 
Hunter, J. (1986). Cognitive ability, cognitive aptitudes, job knowledge, and job performance. Journal of Vocational Behavior, 29, 340-362. https://doi.org/10.1016/00018791(86)90013-8

Ibrahim, M., \& Falasi, S. A. (2014). Employee loyalty and engagement in UAE public sector. Employee Relations, 36, 562-582. https://doi.org/10.1108/ER-07-2013-0098

Ismail, H., Iqbal, A., \& Nasr, L. (2019). Employee engagement and job performance in Lebanon: the mediating role of creativity. International Journal of Productivity and Performance Management, 68, 506-523. https://doi.org/10.1108/IJPPM-02-2018-0052 Jalalkamali, M., Ali, A., Hyun, S. S., \& Nikbin, D. (2016). Relationships between work values, communication satisfaction, and employee job performance. Management Decision, 54, 796-814. https://doi.org/10.1108/MD-01-2015-0003

June, S., Kheng, Y. K., \& Mahmood, R. (2013). Determining the Importance of Competency and Person-Job Fit for the Job Performance of Service SMEs Employees in Malaysia. Asian Social Science, 9, 114. https://doi.org/10.5539/ass.v9n10p114

June, S., \& Mahmood, R. (2011). Exploring The Relationship Between Role Ambiguity And Job Performance Among Employees Of The Service Sector Smes In Malaysia.

Jung, H., \& Yoon, H. (2018). Improving frontline service employees' innovative behavior using conflict management in the hospitality industry: The mediating role of engagement. Tourism Management, 69, 498-507. https://doi.org/10.1016/j.tourman.2018.06.035

Kahn, W. A. (1990). Psychological Conditions of Personal Engagement and Disengagement at Work. Academy of Management Journal, 33, 692-724. https://doi.org/10.5465/256287 Karatepe, O. M., Keshavarz, S., \& Nejati, S. (2010). Do core self-evaluations mediate the effect of coworker support on work engagement? A study of hotel employees in Iran. Journal of Hospitality and Tourism Management, 17, 62-71. https://doi.org/10.1375/jhtm.17.1.62 Khan, M. I. (2012). The Impact of Training and Motivation on Performance of Employees. Motivation.

Koyuncu, M., Burke, R., \& Fiksenbaum, L. (2006). Work engagement among women managers and professionals in a Turkish bank. Equality, Diversity and Inclusion, 25, 299-310. https://doi.org/10.1108/02610150610706276

Kozlov, A. M., Darriba, D., Flouri, T., Morel, B., \& Stamatakis, A. (2018). RAxML-NG: A fast, scalable, and user-friendly tool for maximum likelihood phylogenetic inference. bioRxiv. https://doi.org/10.1101/447110

Krejcie, R. V., \& Morgan, D. W. (1970). Determining sample size for research activities. Educational and Psychological Measurement, 30, 607-610. https://doi.org/10.1177/001316447003000308

Kuranchie-Mensah, E. B., \& Amponsah-Tawiah, K. (2016). Employee motivation and work performance: A comparative study of mining companies in Ghana. Journal of Industrial Engineering and Management, 9, 255-309. https://doi.org/10.3926/jiem.1530

Lawler, E., \& Porter, L. (1967). The Effect of Performance on Job Satisfaction. Industrial Relations, 7, 20-28. https://doi.org/10.1111/j.1468-232X.1967.tb01060.x

Lorincová, S., Starchon, P., Weberová, D., Hitka, M., \& Lipoldová, M. (2019). Employee Motivation as a Tool to Achieve Sustainability of Business Processes. Sustainability, 11, 3509. https://doi.org/10.3390/su11133509

Macleod, D. I., \& Clarke, N. (2011). Engaging for success: enhancing performance through employee engagement, a report to Government. 
Majdalawi, M. A. (2015). Human resource development in Palestinian higher education, with special reference to evaluation of employee development and training at the Al-Aqsa University, Gaza, Palestinian Authority.

Maslow, A. H. (1943). A theory of human motivation. Psychological Review, 50(4), 370. https://doi.org/10.1037/h0054346

May, D. R., Gilson, R., \& Harter, L. (2004). The psychological conditions of meaningfulness, safety and availability and the engagement of the human spirit at work. https://doi.org/10.1348/096317904322915892

Mendes, F., \& Stander, M. (2011). Positive organisation : the role of leader behaviour in work engagement and retention : original research. Sa Journal of Industrial Psychology, 37, 1-13. https://doi.org/10.4102/sajip.v37i1.900

Misra, S. (2013). A study of organizational commitment of B Ed college teachers in relation to organizational support work life balance and ethical leadership behaviour of their principals.

Mohamed, M. S., Khalifa, G. S., Nusari, M., Ameen, A., Al-Shibami, A. H., \& Abuelhassan, A. (2020). Effect of Organizational Excellence and Employee Performance on Organizational Productivity Within Healthcare Sector in the UAE. Journal of Engineering and Applied Sciences, 13, 6199-6210. https://doi.org/10.36478/jeasci.2018.6199.6210

National Center for Statistics and Information [NCSI]. (2019) Statistical Year Book for the Year 2019. Muscat. Retrieved December 6, 2019, from https://www.ncsi.gov.om/Elibrary/LibraryContentDoc/bar_Statistical Year Book 2019_c2111831-e13a-4075-bf7b-c4b5516e1028.pdf

Oetomo, H. W., \& Budiyono. (2020). Work Motivation and Compensation Towardswork Stress And Employee Performance. https://doi.org/10.5373/JARDCS/V12SP1/20201123 Orabi, K. (2018). Performance indicators are absent in the government sector...weak in the private sector. Retrieved April 6, 2018 from https://shabiba.com/article/93145\%D9\%85 Oyovwe-Tinuoye, G. O., Omeluzor, S. U., \& Patrick, I. O. (2021). Influence of ICT skills on job performance of librarians in university libraries of South-South, Nigeria. Information Development. https://doi.org/10.1177/0266666920983393

Parker, S., \& Griffin, M. (2011). Understanding active psychological states: Embedding engagement in a wider nomological net and closer attention to performance. European Journal of Work and Organizational Psychology, 20, 60 - 67. https://doi.org/10.1080/1359432X.2010.532869

Preacher, K., Rucker, D., \& Hayes, A. (2007). Addressing Moderated Mediation Hypotheses: Theory, Methods, and Prescriptions. Multivariate Behavioral Research, 42, 185 - 227. https://doi.org/10.1080/00273170701341316

Price, J. L. (2001). Reflections on the determinants of voluntary turnover. International Journal of Manpower, 22, 600-624. https://doi.org/10.1108/EUM0000000006233 Pushpakumari, M. D. (2008). THE IMPACT OF JOB SATISFACTION ON JOB PERFORMANCE: AN EMPIRICAL ANALYSIS.

Ramos-Villagrasa, P. J., Barrada, J., Fernández-Del-Río, E., \& Koopmans, L. (2019). Assessing job performance using brief self-report scales: the case of the individual work performance questionnaire. Revista de Psicología del Trabajo y de las Organizaciones, 35, 195-205. https://doi.org/10.5093/jwop2019a21

Rasheed, M. I., Humayon, A. A., Awan, U., \& Ahmed, A. U. (2016). Factors affecting teachers' motivation: An HRM challenge for public sector higher educational institutions of 
Pakistan (HEIs). International Journal of Educational Management, 30, 101-114. https://doi.org/10.1108/IJEM-04-2014-0057

Reynoldsa, T., Howardc, C., Sjåstadd, H., Zhue, L., Okimotof, T. G., Baumeisterf, R. F., Aquinoc, K., \& Kimg, J. (2020). Organizational Behavior and Human Decision Processes.

Rich, B., Lepine, J. A., \& Crawford, E. R. (2010). JOB ENGAGEMENT: ANTECEDENTS AND EFFECTS ON JOB PERFORMANCE. Academy of Management Journal, 53, 617-635. https://doi.org/10.5465/amj.2010.51468988

Riduwan. (2012). Cara Menggunakan dan Memaknai Path Analysis (Analisis Jalur).

Saks, A. (2006). Antecedents and consequences of employee engagement. Journal of Managerial Psychology, 21, 600-619. https://doi.org/10.1108/02683940610690169 Schaufeli, W., Salanova, M., González-romá, V., \& Bakker, A. (2002). The Measurement of Engagement and Burnout: A Two Sample Confirmatory Factor Analytic Approach. Journal of Happiness Studies, 3, 71-92. https://doi.org/10.1023/A:1015630930326

Searle, B., Bright, J., \& Bochner, S. (2001). Helping people to sort it out: The role of social support in the Job Strain Model. Work \& Stress, 15, 328 - 346. https://doi.org/10.1080/02678370110086768

Sekaran, U., \& Bougie, R. (2010). Research Methods for Business: A Skill Building Approach (5th ed.).

Sendawula, K., Kimuli, S. N., Bananuka, J., \& Muganga, G. N. (2018). Training, employee engagement and employee performance: Evidence from Uganda's health sector. Cogent Business \& Management, 5. https://doi.org/10.1080/23311975.2018.1470891

Shah, I. A. (2010). Relationship between Rewards and Employee's Performance in Cement Industry In Pakistan.

Shepherd, K., Kervick, C. T., \& Morris, D. N. (2017). Exploring the Research. https://doi.org/10.1007/978-94-6300-824-2_2

Stairs, M., \& Galpin, M. (2009). Positive Engagement: From Employee Engagement to Workplace Happiness. https://doi.org/10.1093/oxfordhb/9780195335446.013.0013

Stewart, G., \& Brown, K. G. (2008). Human Resource Management: Linking Strategy to Practice. https://doi.org/10.26782/jmcms.2019.10.00051

Swapna, P. (2019). Reward and Recognition Impact on Job Satisfaction and Performance in retail sector: an Empirical Study from Andhra and Telangana.

Tahir, N., Yousafzai, I. K., Jan, S., \& Hashim, M. (2014). The Impact of Training and Development on Employees Performance and Productivity A case study of United Bank Limited Peshawar City, KPK, Pakistan. The International Journal of Academic Research in Business and Social Sciences, 4, 86-98. https://doi.org/10.6007/IJARBSS/v4-i4/756 Tamkin, P. (2005). The contribution of skills to business performance.

Tripathy, M. R. (2013). Book Review: Human Resource Management. Vision: The Journal of Business Perspective, 17, 191 - 192. https://doi.org/10.1177/0972262912483991

Truss, C., Shantz, A., Soane, E., Alfes, K., \& Delbridge, R. (2011). Employee engagement, organisational performance and individual well-being: exploring the evidence, developing the theory. The International Journal of Human Resource Management, 24, 2657 - 2669.

Viswesvaran, C., \& Ones, D. (2000). Perspectives on Models of Job Performance. International Journal of Selection and Assessment, 8, 216-226.

Woodruffe, C. (2000). Winning the Talent War: A Strategic Approach to Attracting, Developing and Retaining the Best People. 
Zacher, H., Chan, F., Bakker, A., \& Demerouti, E. (2015). Selection, optimization, and compensation strategies: Interactive effects on daily work engagement.

Zhu, W., Avolio, B., \& Walumbwa, F. O. (2009). Moderating Role of Follower Characteristics with Transformational Leadership and Follower Work Engagement. Group \& Organization Management, 34, 590 - 619. 